Networking Knowledge: Journal of the MeCCSA Postgraduate Network, Vol. 4, No. 1 (2011)

ARTICLE

\title{
Metal, Machismo and Musical Mode: how the 'feminine' Phrygian second has been appropriated and transformed
}

SARHA MOORE, University of Sheffield, UK

\section{ABSTRACT}

Heavy Metal music has made extensive and deliberate use of the 'medieval modes', particularly those starting with a semitone. Historically the second note of these modes, the Phrygian second, was deemed 'weak' and 'feminine', a far cry from the machismo of Heavy Metal.

This paper describes the journey of the Phrygian mode and its semitone second note, from ancient Greek times to the present, detailing changing connotations and the consequences of these on present day Heavy Metal music. The paper will include particular discussion of how the Phrygian second supports machismo through Metal music in film, and the subgenre of Oriental Metal that can challenge the Othering of the Phrygian second.

It can be argued that within Metal the Phrygian second is significant and central to its aggressive power, and that Metal has given the Phrygian second unique and innovative masculine significations that contribute new expressive aspects to the contemporary musical palette.

\section{KEY WORDS}

PHRYGIAN HEAVY METAL FLAT SECOND MASCULINE 
Networking Knowledge: Journal of the MeCCSA Postgraduate Network, Vol. 4, No. 1 (2011)

It stirs something inside for me. If you're driving fast on the motorway, it's hard and it's heavy....it's fight music, heavy, fast and aggressive.... it makes you feel good, like seeing someone scoring a nice goal, the way the ball goes in is so nice and perfect. The same thing happens when you stand in front of a loud guitar amplifier and play a loud note or hit a loud chord and you feel the power going through you, you created that, and there's people in front of you getting off on it too (Luke Raynor personal interview 2009).

Heavy Metal music can be described as a "masculine" genre, the male testosterone force expressed above by Metal guitarist Luke Raynor. The dominant gender in the Heavy Metal "community" is male and the experience of attending a Metal gig is one of brotherhood: you have to be man enough to suffer the volume and survive the physical assault of the "mosh pit", where the slam dancing takes place, which is not to say that women cannot join in, but they must leave their vulnerability behind (Krenske and McKay, 2000: 289-90, Gruzelier, 2007: 64-70, Yildirim, 2009:3-4). This is music for "real men", warriors: an aggressive, transgressive and shocking, expression of homosociality (Walser, 1993: 110). And yet it is still music, not war, it is passionate and communal (Grozelier, 2007: 74).

This expression of masculinity is not simple. Heavy Metal scholar Robert Walser has written on how the genre evolved out of a crisis of masculinity in Britain in the 1960s amongst working class male youth (Walser, 1993: x, 109). They felt emasculated by unemployment, bleak prospects and authorities that were indifferent to their situation. Men were left in a position of not being able to prove their masculinity in a conventional manner by being a "breadwinner". Metal music emerged from these disenfranchised men who were seeking empowerment through the sonic values of the music. It was a violent musical attack on capitalism, 'against the smug security and safety of respectable society' (Weinstein, 2000: 35). A new empowered community was built, to some part reconstructing a patriarchal order within their own lives.

Misogyny was part of the macho posturing and a sign of the essential insecurity of their position. Unfortunately women attracted to the genre for its anti-establishment nature were then faced with this misogyny. Unfortunately women attracted to the genre for its anti-establishment nature were then faced with this misogyny (Krenske and McKay, 2000: 302, Yildirim, 2009: 2). 
Networking Knowledge: Journal of the MeCCSA Postgraduate Network, Vol. 4, No. 1 (2011)

The strength of the male bonding is seen to be contingent on the absence of women and romantic concerns, which could disrupt its strength with what it may regard as "dangerous seductive charms", akin to the ancient sirens. Metal lyrics are sometimes about the dangers of becoming emasculated by the "poison" of women, and the band Iron Maiden, named after a torture device, has a clear metaphor of these dangers (Krenske and McKay, 2000: 290, Walser, 1993: 116, Yildirim, 2009: 5-8). Male bonding and homosociality create a community that is not about individual relationship, but about a larger brotherhood.

The brotherhood of Metal sees women as subversive and dangerous, yet Metal music itself embraces the subversive and dangerous, as well as other "feminised" concepts within the dualisms of binary thinking: irrational, evil, disturbed, dangerous, other. So the Other that is woman, "subversive and dangerous", is on the same "side" as irrationality, evil, madness and horror: common themes in Metal lyrics. It is this paradox that lies at the heart of this paper. Heavy Metal scholar Robert Walser writes that 'Heavy Metal explores the Other, everything that hegemonic society does not want to acknowledge, the dark side of the day-lit enlightened adult world' (Walser, 1993: 162). The genre wallows in Otherness, presenting it as challenging, often "subversive and dangerous", yet this is assuredly masculinist music, the "subversion" often being in the form of macho posturing and individual assertion. It could be argued that there is an element of usurpation of the "wild side" from women, who remain regarded as domestic or sex objects in the Heavy Metal milieu (Weinstein, 2000: 36).

The Dionysian hero of Metal is a great warrior, ready to fight dirty, a hero for our times, not the classic Apollonian warrior: rational and honorable, but a Dionysian warrior: irrational and allied to Chaos (Weinstein, 2000: 35). The Metal warrior may be taking to the white working class male body many masculine attributes of a "real" man, full of machismo, far from the "sissy" bureaucrat who may have power over him - or indeed be reflected in his own employment, creating a Jekyll and Hyde effect, or perhaps a Superman identity.

In Metal an angry music was created, harder and heavier than rock, emphasizing the dark side, offering the opportunity to release violent drives suppressed by the norms of mainstream society, railing against injustice (Deanna, 2008). Musical elements within Heavy Metal support 
Networking Knowledge: Journal of the MeCCSA Postgraduate Network, Vol. 4, No. 1 (2011)

these sentiments: violent lyrics, loud distortion, and gunfire like percussion. In this article I will present another element that, I argue, underpins Metal music's power in a more hidden and ominous manner: the musical interval of the flat or Phrygian second. The Phrygian second has found a home in Metal music, depicted as threatening and depressing, yet exciting and alive in its dissonant tension (Moore, 2010: 136). This musical element, as it appears in Heavy Metal, is an aggressive re-working of a musical motif that occurs in other genres, though very rarely in Western genres, and here the motif forms new and dramatic significations. By tracing the journey of the Phrygian second through history I will shed light on some of the hidden and ominous connotations that enable this note to take the central position that it has in present day Heavy Metal music.

\section{Metal and the flat second}

Each generation brings new connotations to musical motifs in popular music, often as a rejection of previous trends or as an attempt to revitalize older traditions. The established meanings of a motif are not necessarily relevant to the new formation, and there may or may not even be an awareness of those meanings, yet there is often an emotional "tug" due to the sedimented connotations (Killick, 2001: 186, Ra'ad, 2005: 376).

By discussing the connotations of this particular musical sign I hope to illustrate how popular culture can transform the signification of a motif, from "weak" origins, through the exploitation of its transgressive nature, to popularity as "something different and shocking" to a place within new masculine ideologies.

Compared with the familiar Major scale: Doh $R e \mathrm{Mi}$, the second note is flattened to get Doh $R a \mathrm{Mi}$, which quite changes the effect. Cognitive Psychologist David Huron, in his book Sweet Anticipation: music and the psychology of expectation describes how when expectations are confounded, in this case by a note being lower than the familiar, there is an emotional reaction: 'The most predictable tones and tone sequences tend to be experienced as the most pleasant' (Huron 2007: 173). 
Networking Knowledge: Journal of the MeCCSA Postgraduate Network, Vol. 4, No. 1 (2011)

It's the use of this flattened second note within Metal that is the subject of this article. It makes a very narrow pitch change, a semitone, from the note known as the key-note, and this change gives an added tension that effects its emotional impact, due partly to these confounded expectations. Metal bass guitarist Pete Herbert here refers to it as the minor second:

John Williams was the first time I heard it: Jaws....A riff with minor second makes it more interesting, really "doomy"....That's what you wanted...Angry young kids, rebel without a clue...just want to make noise....It suits the style, not...something pretty in a Major scale....It also suits the stagecraft of it all, that you can mosh whilst playing a riff based around a root and a minor second. You can jump around to the minor second riff, say E to F, without playing a wrong note. Unison guitar and bass locked in for riffs. Tribal, all knocking your heads. I think it's those two things: the image, the movement, the physical stagecraft, performance and what a minor second does to you as a human, you know on a human level. It creates the skull and the spiral to Hell (Pete Herbert personal interview 2009).

Two issues arise here: Herbert's comment on "moshing" refers to the ease of playing the lowest string (E) on the guitar, alternating with a first fret note $(F)$, the Phrygian second, and that this can be done while jumping around, guitar and bass "locked in" together. Then "The spiral to Hell": the descending resolution of this flat second to the key-note has associations commented on by Tagg: 'the affect of melodic descent using small intervals probably date[s] back to at least the pre-Baroque and its notions of music's rhetorical devices like katabasis, [descent into hell], a fitting concept in the context of sadness and death!' (Tagg, 1993: 60 note 19). The hero's narrative established in post Medieval times was a discourse of upward striving, escaping from the low and murky depths, conquering all with the hero's positivity (Taylor, 2007: 17-18, 28). Pete Herbert's comment on the "spiral to hell" shows that contrasting associations are abiding and evocative within an anti-heroic framework.

The Phrygian second is ubiquitous in Metal music, recognised as a mainstay of the contemporary Metal sound (Pieslak, 2008: 35-52, Walser, 1993:46-7, Cope 2010: 4). It is not used to any extent in contemporary pop, rock, folk, rhythm and blues, or punk, though there has been a certain presence in trance music where it has associations of emotionality and mesmerism. Raynor states: 
Networking Knowledge: Journal of the MeCCSA Postgraduate Network, Vol. 4, No. 1 (2011)

In Heavy Metal the Phrygian...really works in terms of a dark Heavy Metal sound scale....a very sinister connotation to it.... Most rock...was pentatonic [a scale with only five notes and no semitones]. In the 80 s Heavy Metal came in with solos that weren't based around the pentatonic....It's also intense and memorable with the...flattened second. It's instantly recognisable. With Heavy Metal you want that intensity, everything's harsh....It was influenced by people who'd been classically trained and realised that this would work over the Heavy style....The scale is definitely not happy. (Luke Raynor, personal interview 2009).

Early Metal bands gravitated toward the Phrygian mode for various reasons: Deep Purple were at the forefront of the explorations into classical style virtuosic playing that have been a hallmark of Metal. The classical harmonic minor scale mutates easily into a type of Phrygian mode called the Phrygian Dominant mode. This scale was often used in Richie Blackmore's soloing, as in the 1974 track “Stormbringer" (2’20”). Elaborate guitar playing in Metal, despite its professed intent to display a potent and masculine virility through virtuosic playing, can objectify the guitarist in its flamboyance. Walser writes that this 'suggests a disturbing similarity to the disdained emotional outbursts of women' (Walser, 1993: 108). Gender issues also arose regarding Robert Plant, in another pioneering Metal band Led Zeppelin, who had an ornate and virtuosic style of singing, again traditionally feminine (Fast, 2001: 43). Striving for difference took them to the Other and confusions of binary thinking discussed above. Their 1969 track "Dazed and Confused" uses falling chromatic lines as a backdrop and holds the flat second significantly at a midpoint cadence, before falling to the keynote (3.15-3.30).

Anything that differentiated their sound from pop and embraced dissonance was explored by early Metal bands. The tritone interval [flat fifth] has been written about in Metal due to its epithet of "the devil's interval", and the flat second also gathered importance in the genre. Dissonance was particularly emphasised by the band Black Sabbath, embracing the Chaotic. Andrew Cope writes:

Black Sabbath appear to have adopted and contextualised certain key intervals in ways that Led Zeppelin did not. Those intervals, namely the flat 2 nd and the tritone were the cornerstones of the guitar riff output of Black Sabbath from 1969 to $1975 \ldots$. the effect 
Networking Knowledge: Journal of the MeCCSA Postgraduate Network, Vol. 4, No. 1 (2011)

of these intervals contributed to and related significantly to their music, lyrical and visual image. Moreover, the originality of this sound was one that contributed to the evolution of heavy metal, as a genre, by the establishment of a whole new set of musical conventions (Cope, 2010: 51-2)

The Phrygian second is prominent in Black Sabbath's 1970 track "Hand of Doom": The bass line between has the falling pitch between the flat second and the key-note (3'30" to 4'10').

The Arabic maqam [a kind of scale] called Hijaz is the same as the Phrygian Dominant mentioned above and the concurrence of the flat second in these in both Metal music and music from the Other of the East has brought another stream to Metal. Philip Tagg writes about the Phrygian mode: 'From a Eurocentric viewpoint, this is the mode of Spain, gypsys, Balkans, Turks and Arabs....music from 'somewhere else' (Tagg, 2003: 319). Metal Scholar Keith KahnHarris writes that: 'The Phrygian is associated with oriental musics, such as flamenco' (KahnHarris, 2007: 31). The associations between the East and the "alluring" female are also relevant here. The band Iron Maiden was exploring tensions between reality and dream, evil and power. They were essentially interested in "liberation" through such sources as alchemy, lost Egyptian dynasties and myth (Pillsbury, 2006: 121). Their 1984 track "Powerslave" has Egyptian references and the chorus "Tell me why I had to be a Powerslave, I don't wanna die, I'm a God, why can't I live on?" and the central bass and guitar riff of Powerslave uses the Phrygian Dominant mode.

The flamboyant displays, including makeup and big hair, became more central in Glam Metal in the 80s. Lyrics were more often concerning love and lust and the female audience soared (Weinstein, 2000: 47). Virtuosic guitar playing reached new heights with Van Halen and Yngwie Malmsteen, using the modes extensively. Malmsteen has made a video of explorations on the Phrygian mode. ${ }^{1}$ Van Halen's "Eruption" (1978) has flamboyant soloing that develops from the pentatonic to the Phrygian mode (Walser, 1992: 272).

Fragmentation occurred in the 80 s with important sub-genres developing. These subgenres were primarily as a reaction to the perceived "de-masculinisation" of the genre by Glam

1 http://video.google.com/videoplay?docid $=5789643979090107390 \#$ (accessed $2^{\text {nd }}$ June 2011) 
Networking Knowledge: Journal of the MeCCSA Postgraduate Network, Vol. 4, No. 1 (2011)

Metal. Speed and Thrash Metal were harder and heavier, embracing the Chaotic, more than the Dionysian (Weinstein, 2000: 50). The simplicity of the key-note to flat second riff continued to be effective and the "dissonance" of the Phrygian mode found especial favour in this fundamentalist sub-genre. There was less emphasis on flamboyance and more on death and destruction. An example of this is the band Slayer's 1986 track “Angel Of Death", the bass and guitar riff an oscillation between the key-note and, in turn, the flat second then the unflattened second.

Five years later the hugely successful 1991 album The Black Album from Thrash Metal band Metallica has a prominent flat second motif in the track "Wherever I May Roam", which begins with a delicate sitar version of a key-note to flat second motif then, like in the history of Metal itself, the track restates the motif in a "heavy" version. Later metal bands also frequently drew on the use of the flat second, for example the Armenian-American band System of a Down's 1998 track "Sugar” has a falling chromatic bass riff with the flat second.

In 21st century Extreme Metal music the Phrygian second can be one of the remaining 'musical' features in a harsh sonic landscape. Thrash Metal Trivium's 2005 track "Pull Harder on the Strings of Your Martyr" has a heavy, speed drum feel and a principal bass line built around an oscillation between the key-note to flat second, as is Drowning Pool's 2001 track "Sinner". Arch Enemy's 2003 track "Dead Eyes See no Future" demonstrates how the Phrygian second continues to be given a prominent position in contemporary metal tracks, with a bass and guitar riff of flat second falling to the key-note together with a virtuosic Phrygian guitar solo.

The classic metal formula of flamboyant guitar solos over the "locked in" guitar and bass remain popular. Herbert states: 'As a bass player you can play a simple E minor to F bass riff while the guitarist paints a Locrian-based image [another flat $2^{\text {nd }}$ mode], a Hieronymus Bosch solo, images of Hell, over the locked in semitone bass' (Pete Herbert personal interview). The Phrygian second has been a significant element in every sub-genre of Metal music over 40 years. As this flattening of the second is remarkably rare in the Western pop and classical music that we may have grown up around and take as normal, it is all the more significant that it is such a pervading element in a "popular" genre such as Heavy Metal. 
Networking Knowledge: Journal of the MeCCSA Postgraduate Network, Vol. 4, No. 1 (2011)

\section{The inherited codes of the flat second}

To partly explain this presence we need to look at the history of the flat second in European music, in particular the connotations of the name Phrygian, negative associations of which may have contributed to present-day musical codes. Paradoxically these were often connected with the effeminate.

Phrygia was a remote area to the East of the domain of Ancient Greece, and instruments and music from there were considered foreign (Barker, 1984: 15). The main Phrygian instrument was a wind instrument called the aulos, which was capable of having a very complex and expressive sound (Wyss, 1996: 26, Barker 1984: 51). Plato, in the $4^{\text {th }}$ century BC developed a moral ethos that frowned on the 'complexity' of the Phrygian aulos sound, in contrast to the "manly" simplicity of the Dorian mode played on stringed instruments. Ever since this time the Phrygian mode has been tainted with disapproval (Barker, 1984: 99).

Gilbert Rouget argued that the aulos played music containing more semitones than stringed instruments of the period and, as above, we are presented with familiar binaries:

Musically, it is clear that a mode able to make tone-semitone contrasts must offer much greater expressive possibilities....[producing binary] oppositions: calm vs agitated, virile vs effeminate, worthy vs unworthy, aristocratic vs plebian, beauty vs banality, educational vs entertaining. The Phrygian side of this opposition [the right hand side] could be summed up in one word: release....their effect was due less to their musical characteristics than to the fact that they were signs: signs of Phrygia, the land from which Dionysus himself had come, in short, from the cradle of Dionysus worship.'(Rouget, 1985: 224-5).

So the Phrygian is placed on the feminine, "Metal" side of the binary split: irrationality and release, and associated with an "effeminate agitation" rather than a manly rationale. By the fourth century A.D. these associations became more ingrained within the music itself. The playing of the aulos in the Phrygian mode was often reported to incite men to frenzy, passion and 
Networking Knowledge: Journal of the MeCCSA Postgraduate Network, Vol. 4, No. 1 (2011)

violence. A change of mode to Dorian calming the temper (Rouget, 1985: 228-9, Powers, 2001: 798).

What has been missed out of this tale is the actual notes played in the Phrygian mode and here there is a tale to recall: The Phrygian mode of the Greeks has no relation to that of today. The particular collection of notes described as the Phrygian mode since medieval times was plucked out of the air, as a convenience, in the $9^{\text {th }}$ century AD (Powers, 2001: 381, 398). Hence any associations since that time for the Phrygian mode, with its flat second, can only be connected to Ancient Greek connotations by the coincidence of the name.

Yet associations did continue: The Phrygian mode was described in medieval times as the war-like mode, and continued its Greek connotations, through to the Renaissance, of inciting passion and anger. The New Grove dictionary of music quotes an anonymous writer from the 16th century who, seeking to justify the inclusion of this scale within liturgical texts, wrote: "Since this mode is harsh and inciting to wrath and war, it is suitably applied to those matters where something of bravery or power is shown...Through which the devil was conquered, and the world was rescued through the blood of Christ" (Powers, 2001: 798). This is quite a turn around, giving an ecclesiastical blessing to the "wild release" of the Phrygian mode. How much these connotations were a theoretical construct rather than a living reaction to the mode is unclear, but I will recall them later in this article.

There is also an abiding association in medieval texts between Phrygia, wantonness, and effeminacy: Leach writes of the association of Phrygia 'with classic orientalist tropes of irregular sexual behavior', and quotes the $11^{\text {th }}$ century writer Johannes who wrote how the '"incomplete Phrygian men [referring to eunuchs]... garb themselves like women"' (Leach, 2006: 2,7). The effeminate interpretation of this "passionate" and "wanton" mode is expressed in a nineteenth century Encyclopedia Britannica entry which tells that the Phrygian mode itself is 'alleged by some as an argument of their [Phrygians] effeminacy' (Maclaren, 1823). Remember that the notes of the Phrygian mode here are quite different to those garnering similar associations in Greek times. What may be in common is the importance of the semitone interval (Fast 2001: 44). 
Networking Knowledge: Journal of the MeCCSA Postgraduate Network, Vol. 4, No. 1 (2011)

More concrete historical connotations concerned the flat second interval, the semitone. Early medieval theorists found the presence of the semitone to be a moral problem: how could this "imperfect" interval be part of the 'harmony of the spheres' (Kepler, 1997: 465). Elizabeth Eva Leach points to how some medieval theorists regarded the semitone as an incomplete tone and as morally dubious, the listener's moral fibre being undermined on hearing it. Leach writes of the feminine nature of semitones, tracing this signification from Greek antiquity through to 14th century counterpoint, likening the semitone to an effeminised tone. (Leach, 2006: 6). Linda Austern quotes the $17^{\text {th }}$ century theorist Charles Butler writing that "effeminate lamentations, sorrowful passions, and complaints are fitly exprest [sic] by the inordinate half-notes [semitones]" (Austern, 1998: 41).

The Phrygian second, being a semitone above the key-note, was thus coded as soft and given a feminine, sorrowful description, as opposed to the "natural" whole step that is described as firm, austere and masculine (Leach, 2006: 8). For instance Johannes Kepler writes on music and gender in 1599:

For as woman is made chiefly to be passive, man to be active, especially in the act of generation, so the soft kind is fitted for the feminine motions of the mind, the hard for masculine activities.... [When] things are upside down, so that there is a semitone in the lowest position...Phrygian to the ancients, it agrees with this reversal of the order of nature that they sound plaintive, broken, and in a sense lamentable....sadness and languor of the mind [or perhaps] pleasurable sadness, as when we are pleased with softness of mind, with loves and desires, or when joy expresses itself in tears (Kepler, 1997: 240, 243-5).

Kepler is here clearly associating the notes within the Phrygian mode as we know it today, with its flat second, with femininity and lament.

In the late medieval period the rise of musical tonality, the now standard major and minor scales, brought the subsequent demise of the modes, which were seen to lack the masculine 'thrust' of the major scale (Taylor, 2007: 17-18). The Phrygian mode held a particular problem within this harmonic framework due to its flat second note, and was labelled illegitimate. Musicologist Susan McClary explains how within the conventional harmonic 
frameworks established in the Renaissance 'it [the Phrygian] does not have the apparatus that could make its meanings clear', and so it was 'unsuitable for the vast majority of situations' (McClary, 2004: 82). Since the Medieval era the Phrygian mode appeared in Western composition only occasionally, to support expressions of grief and anguish or, more recently, the exotic as in other parts of the world, including the Middle East, the Phrygian mode remained widely used.

So the rare occurrence of the flat second in Western music after this time has connoted pathos, anguish or equivocation as in the $16^{\text {th }}$ century madrigal named $O$ Dolce Notte (Oh sweet night), by Verdelot, which emphasises the movement from the key-note up to the flat second and back: McClary has described this as a "nocturnal arch" that haunts the madrigal (McClary, 2004: 48-51). A later example is the Chopin Valse Brillante in A Minor, from the19th century, described by one reviewer as showing "the "other" side of Chopin: full of melancholy, gloom and grief, expressed in mournful simplicity', ${ }^{2}$ and by another: 'he positively bathes himself in languor and longing throughout.' The waltz starts in a Major scale and then changes to use the Phrygian mode. The reviewer in the online magazine Classical Archives described this change of mode as a 'bittersweet inspiration'. ${ }^{3}$

So the codes are generally passive and sad, though a "bittersweet" element resonates with Rouget's comments above on "pleasurable sadness". The "war-like" connotations have dropped away. Musicologist Deryck Cooke described the flat second interval as 'an expression of anguish in a context of finality, a hopeless anguish' (Cooke, 1959: 78). All these connotations have been transmitted to anyone who has grown up in Western cultures, we are so enculturated with certain musical codes that we react unthinkingly to them. McClary described the effect of the flat second: 'In the physical bodies [in the Western World] that are accustomed back to the $15^{\text {th }}$ century it is going to sound profoundly alien, and there may be even a physical reaction'. ${ }^{4}$

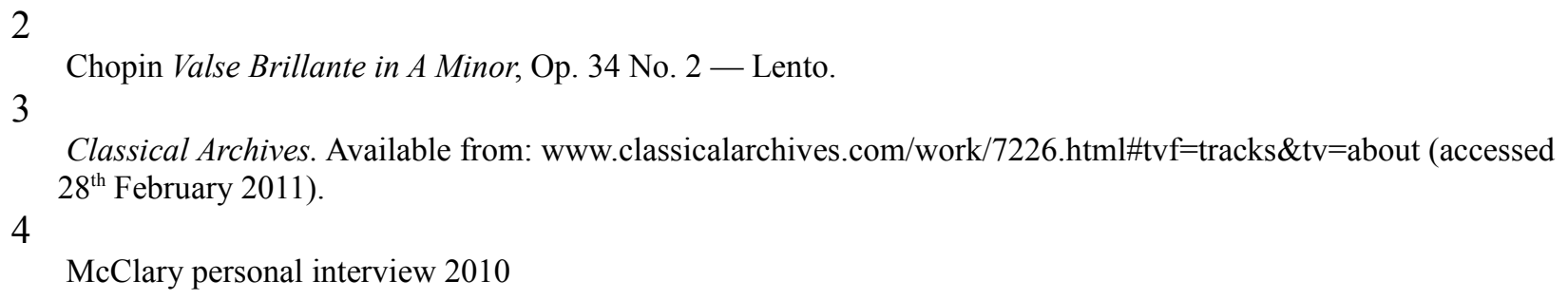


Networking Knowledge: Journal of the MeCCSA Postgraduate Network, Vol. 4, No. 1 (2011)

Musical motifs containing the flat second signify the Other, the note itself being Other to the "normal" choice of musical notes in Western genres. Tagg writes that "the Phrygian is obviously neither default mode not default melodic vocabulary' (Tagg and Clarida, 2003: 319). The inherited connotations from hundreds of years of associations are of the Other in any guise: weakness, femininity, stasis, anguish, the alien, Eastern. The listener in the West intuitively recognises the Other in its appearance.

\section{Panning out for Metal}

Clearly these associations can be very pertinent in the Metal genre that lauds instability and discomfort. McClary writes of how the "problems" of the Phrygian mode can be turned "into a strength if one wishes to simulate such an uncomfortable affective realm.' (McClary, 2004: 968). McClary continues:

The Phrygian usually lies dormant within the system' she says 'but...can be conjured up...when called upon to help spew out particularly harsh affective states....Heavy Metal...bands such as Metallica and Megadeth adopted Phrygian as their modus operandi" (McClary, 2004: 209).

The 'dissonant' Phrygian second appeals to the shocking nature of the genre. Its "dormant" nature also has Gothic connotations for Heavy Metal followers. It is known as one of the "medieval church modes" by jazz musicians, and since Black Sabbath's fascination with Gothic horror films and all things medieval this has been significant in its presence in Metal music, playing with images of the Devil and the "blood of Christ" (the "emboldening" for battle connotation expressed above).

The original associations strengthen the new adapted meanings: Walser describes Metal music as: 'build[ing] on the sedimented content of musical forms and cultural icons' (Walser, 1993: 170). This is echoed by Metal scholar Keith Kahn-Harris: 
Networking Knowledge: Journal of the MeCCSA Postgraduate Network, Vol. 4, No. 1 (2011)

Certain modes have long had particular associations and connotations, with the Phrygian and Locrian seen to have the "darkest" sounds. Both Phrygian and Locrian are used sparingly in Western music.... Where extreme Heavy Metal appears to differ...is that it 'lightens' these modes to a far lesser extent....Extreme Heavy Metal represents a sustained and austere exploration of 'darker' modes that have long been associated with danger and evil (Kahn-Harris, 2007: 31).

So by combining the flat second musical motif in a low frequency and with a loud volume its association may change from pathetic to aggressive, to a new anti-heroic identification. The Otherness of the sound of the flat second is transformed from having a passive connotation to a threatening and thus powerful one, more associated with a wild beast than a moan. The Other that was weak, becomes strong, a radical force. It can be argued that music that is merely fast and loud would not contain the deep sense of transgressive threat that the flat second gives at the heart of Metal music.

\section{Metal and the "beast" in film and war.}

In the final decades of the twentieth century the Phrygian second began to be used in Hollywood films as a code for "beast", the tension of the semitone movement from key-note to flat second supporting tense, doom laden associations, of a different sort of aggressive Other (Cope, 2010: 54). John Williams' music for the 1975 film Jaws made the Phrygian second famous with the approaching shark being heralded by the semitone motif, increasing in tempo as the danger gets closer. The character of Captain Quint in the film is a "super masculine" shark hunter, assured that he is the only one to be able to conquer the menace of the rogue shark. He dies in a duel with the shark and here there are echoes again perhaps of the sirens in his watery fate. This film brought in a new "grand film style" returning to themes of 1950s horror movies, resonating with the Metal lust for gore and its own inspiration from early Gothic horror movies. "Bestial" connotations in Hollywood overlap with power and macho connotations in Metal and this has resulted in Metal music also appearing in thriller movies, coded for action, adventure and violence (Pieslak, 2009: 77). 
Networking Knowledge: Journal of the MeCCSA Postgraduate Network, Vol. 4, No. 1 (2011)

Heavy Metal's extensive use of the flat second as part of its powerful, loud, masculine, threatening sound is also exploited in recent films set in wars in the Middle East, combining the Other as East and the Other as "beast", here meaning a military enemy. In the 2008 film The Hurt Locker, set during the Iraq war, there are three tracks played from American Industrial Metal band Ministry. The masculinity and machismo of the main character Sergeant James is underlined by his listening to the track "Khyber Pass" which combines "Arabic" singing with a Metal track using a flat second to key-note bass riff. One of the film's music composers, Marco Beltrami, described how the concept of the music for the film was essentially diegetic, developing the sounds of an "alien" landscape ${ }^{5}$. The final credits are accompanied by a repeat of "Khyber Pass" as a leitmotif for James's character. This could be heard simply as "pumping-up" music for battle.

Soldiers in the scene of battle often listen to Metal music to psych themselves for battle and Samir Puri writes that sometimes this is lyrically specific, such as Metallica's "Seek and destroy" being listened to by mobile patrols (Puri, 2010:60). Some of the most famous Metal bands, such as Black Sabbath and Metallica are politically left wing in their lyrics, anti-war and against real violence, yet, perhaps as an inevitable consequence of the violent macho music, there is much re-interpretation of Metal music, particularly within a contemporary war setting.

The song "Bodies" by American alternative Metal band Drowning Pool, which was written about the brotherhood of the "mosh pit" has a chorus line: "Let the Bodies Hit the Floor". Journalist David Peisner writes: 'Nearly every interrogator and soldier I spoke to mentioned the aggro-metal outfit's 2001 hit "Bodies", with its wild-eyed chorus, "Let the bodies hit the floor!", as a favourite for both psyching up U.S. soldiers and psyching out enemies and captives' (Peisner, 2006: 91). It has been taken out of context on many occasions and used in connection with violence and war, including in the films Stop-Loss, Fahrenheit 9/11, Soundtrack to War and the Rambo 4 trailer (Sumera forthcoming). The lyric and the backing music of "Bodies" are both melodically built on McClary's "nocturnal arch" from the key-note to the flat second and back.

5

6

The Hurt Locker CD liner notes

'Military Clip let the Bodies Hit the Floor'

ISSN 1755-9944 
Metal music is being played at present in the advertising of almost all branches of the armed services (Pieslak, 2009: 41). The subversive Metal genre is co-opted into the mainstream, still appealing to young working class men's desire for excitement and power.

The Metal ideology of power through transgression takes the musical coding far from classical heroic music. The common concept of heroic music may be marches, the Major scale: think of "Oh When the Saints" or "Land of Hope and Glory". So the arrival of the flat second with its connotations of "sinister" and "Eastern" is notable. The 1960's U.S. Marine recruitment music video contained military marches. ${ }^{7}$ In the latest U.S. Reconnaissance Marine Recruiting Video there is an oscillation between the key-note and flat second, firstly under the image of an Eastern man with a weapon, and captions regarding the threat from terrorism; then continuing more menacingly with an American soldier in a stealth image with a caption "We are watching you", a skull image with a motto "swift, silent, deadly", followed by Heavy Metal music supported by an electric guitar playing fast repeated key-note to flat second. I argue that this recruitment video is underlining a perceived threat to the American way of life from the "East" by using the "Eastern" flat second almost subliminally under the image of the Eastern man, and then it being appropriated by a sinister and powerful image of a U.S marine. ${ }^{8}$ Again, the sinister and dangerous is complexly situated both without and within the American subject.

The American ethos of personal freedom over an evil enemy can justify "dirty fighting" as the Metal genre may be seen to advocate. The "hero" and the "anti-hero" sometimes become blurred. When faced with the underhandedness of "terrorism", it might be argued, the hero can be no saint. Slavoj Zizek writes of how the hero is "immoral, yet ethical - that is to say, he violates...existing explicit moral norms in the name of a higher ethics of life, historical necessity, and so on" (Žižek, 1994: 67). Ian Biddle and Freya Jarman-Ivens describe the modern hero as:

An uncompromisingly self-serving figure, one who strives for his own preeminence. And it is indeed this kind of formation of the masculine which is

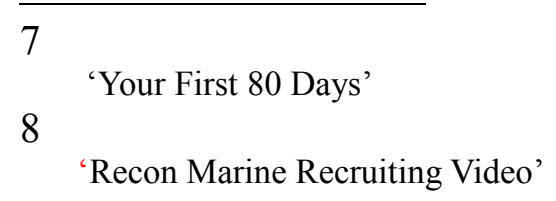


Networking Knowledge: Journal of the MeCCSA Postgraduate Network, Vol. 4, No. 1 (2011)

culturally reified: those figures exalted as heroes (certainly by Western cultures) are characterised by their "drive", their "single-mindedness", but not (typically) by their commitment to the "Good of others" (Biddle and Jarman-Ivens, 2007: 13).

This can describe the ethical position of the Metalhead, striving for personal expression and power, rather than the good of others. The "subversive" aggression of Heavy Metal can be as strengthening to the soldier in battle as a military drum. The Metalhead, in striving for empowerment, may also be striving to be a hero. The role that the flat second plays in this "subversive" aggression within a film track is to "reinforce the cultural associations of malevolence, fear and distress associated with the flat $2^{\text {nd }}$ (Cope, 2010: 53-4). The ominous connotations of the flat second, the tension with its downward resolution, and the Otherness of its presence all contribute to its effectiveness in a film sound track to support tension building and an "underhand" approach (Cope, 2010: 19). A complex of sedimented meanings empower the flat second to support film, video and military situations with a "diabolic" and aggressive threat.

The combination of Arabic music and Metal music, as described above, is partly achieved by the prominence of the flat second in many Arabic maqamat. Arabic music and its people have a history of being described in an Orientalist fashion as weak and effeminate (Said, 1978: 40, Taylor, 2007: 61). Clearly this is effectively exploited within military situations in the Middle East. When codes of East and beast are brought together in a Middle Eastern war setting, through the commonality of the flat second motif, these Othering connotations are being reinforced. The Arab as threat has clear resonances with the feminine as threat, both being intertwined in the discourse of the Oriental (Taylor, 2007: 51).

\section{Oriental Metal}

The prevalence of the flat second in musics of the Middle East, South Asia and North Africa has eased the combination of music from these traditions with Metal music, and this has been exploited by many different bands, bring up new positive connotations. Glenn Pillsbury has ISSN 1755-9944 
Networking Knowledge: Journal of the MeCCSA Postgraduate Network, Vol. 4, No. 1 (2011)

written extensively on the role of the Phrygian second in Metallica's 1991 "Wherever I may Roam", where a motif with the flat second is repeated first on an electric sitar then with a heavy guitar and bass riff: 'the distinct Phrygian sound of the riff, and that sound's function as one of the most common markers of exoticism, frames the imagery of the road in "Wherever I may Roam"'. (Pillsbury, 2006:101). An exotic scene is evoked by the Phrygian melody on the sitar, then the adoption of this melody by the Metal genre can suggest an ownership of this exotic location by the singer and audience. This, again, has resonances with the manner in which the Phrygian mode itself was wrenched from its feminine connotations by the Metal genre.

The Danish musician Jesper Boye describes the internet band Al Qaynah, that he produces, as being metaphorically from Afghanistan in a political protest against the "war on terrorism". It mixes music from musicians in many countries, in particular from the Middle East and Metal. Their tracks, such as "Ground Zero Pilgrims" strongly feature the flat second as a common feature of the many genres used, with a notated Arabic maqam with flat second as an image on the website. Instead of power over, the juxtaposition here is presented as of equal partners, giving masculine credibility to the Eastern artistes involved.

The easy combination of "gentle" Arabic melody with the harshness of the Metal genre is exemplified by the subgenre of Oriental Metal, which originated with the Israeli band Orphaned Land in the 90s and has now extended to Palestine, Egypt and America, amongst other countries. Established codes for the flat second in Metal are challenged and extended by the use of Arabic scales and instruments, introduced for contrast and self-identification in the quiet sections, often, as in "Wherever I may Roam", at the start and end of tracks.

The flat second is not an Other to the Oriental Metal musicians that I interviewed, as it is ubiquitous in the musical traditions that they grew up with. This inevitably alters the connotations of the flat second within the Metal genre that they inherit from the West. Simplistic binaries of East-West, woman-man, irrational-rational are broken down within Israel: Yossi Sa'aron Sassi of Orphaned Land is a Mizrahi Jew with Libyan and Iraqi parents. Middle Eastern music was sung and played in his childhood home and he plays the bazouki, saz and oud [stringed instruments from the Middle East] interchanging with distorted electric guitar in 
Networking Knowledge: Journal of the MeCCSA Postgraduate Network, Vol. 4, No. 1 (2011)

Orphaned Land. He spoke of the difference in the use of the flat second between his own band and Western Metal bands:

I think a lot of people in Metal in the Western World play it because...it has that half tone diabolic, bad boy kind of essence to it.... All the things that are like you know quite dissonant to the ear....they do something that is Phrygian...Metal is used to being a bit dissonant, out of scale notes.... Many bands just do because they want this contrast, the sound of this half-tone games and to sound a bit diabolic...tough....but for me it's really nothing about that. I don't try to be diabolic and to create any controversial sounds, or dissonant sounds in any way. For me it is far from dissonant (Yossi Sa'aron Sassi personal interview 2010).

The "bad-boy" image, and the complexities of masculinity, Metal and Middle Eastern politics thus pan out differently in the performance of Orphaned Land's music. Their 2010 album The Never Ending Way Of ORwarriOR has a concept of us all being warriors in a "battle for light" [Or is the Hebrew for light], in the sense of finding peace and building bridges between nations. They have a large following in Arabic countries that delights them, strengthening their belief that the "universal language" of music is constructive within Middle Eastern politics. Sassi quotes a Jordanian audience member at a performance in Istanbul:

"I was raised and taught to kill you. I have a primal drive to do you harm...as soon as I heard the mix [within Orphaned Land], the mix of harmonic scales from my childhood, my father's music, my homeland music, with the Western music this mix was magic to me. I remember saying to myself "how can this be, because it's a Jewish band...the people who wrote this music cannot be that bad, they cannot be that evil". ...He said to me "Thank you for making me more open-minded" (Yossi Sa'aron Sassi personal interview 2010).

Unpicking the complexities within these statements is beyond the scope of this article. I will simply note that the desire to use the confluence of the Arabic and Metal notes to enable peaceful communication is notable, a non-aggressive assertion.

The Palestinian Oriental Metal band Chaos use their local Arabic music in their Oriental Metal music: Their 2011 track "Silence before Chaos" starts with an extended Arabic melody, 
played on the qanun [an Arabic zither], beginning with a key-note to flat second motif that, as in other Metal tracks, is taken up as the bass line in the subsequent Metal track. Chaos guitarist Firas Nadaf sees his music as making a powerful message of peace and truth:

The feeling of Heavy Metal is powerful....We say the truth and only the truth....Lyrics are not happy songs, not "Oh I was born in a happy country".... since the beginning of time people were fighting over land. Man was born to fight over these things.... The devil is winning; people are following the killing, the war. Why can't we live in peace ....That's what we want in Chaos - humanity is fading...the world is coming to an end somehow...This is why Chaos plays...We came with a message, we're not just making Heavy Metal because Heavy Metal rules. No, if we had a great country, if we were living in a great place we'd be making soft rock or soft songs.... the way I see it I came from a place that has never...has no good...has no peace. What am I going to say?...To the people living here to raise the mask from their eyes. (Firas Nadaf, personal interview 2010).

Political associations were brought up for Nadaf directly concerning the flat second: 'It's tight, like Israel', he said. ${ }^{9}$

These Oriental Metal artists are selling their own unique music in radical ways, reflecting contemporary life with its strife and complexity: two Metal bands, one Jewish, the other Arab both speak of Middle Eastern music being their ground, the Metal sound being their milieu. Without there being a clear connection between the flat second and the Other in the Middle East the potential for expression using this note becomes much more nuanced, even within the "brutalized" genre of Metal. The embracing of the flat second as a powerful, expressive symbol that occurs in Metal can, I would argue, be used for clearer statements of selfidentity and masculinity, without the tainting of the Other. The "masculine" connotations acquired from the Metal genre can be transferred to the flat second within Arabic music, enabling young men in the Middle East further empowerment through their own local musical resources.

9

Firaz Nadaf, personal interview 2010 
Networking Knowledge: Journal of the MeCCSA Postgraduate Network, Vol. 4, No. 1 (2011)

\section{Conclusion}

The Phrygian second that had been coded as feminine became, in Metal music, an agent for the expression of male power. In Medieval times the semitone's theoretical "imperfection" was mapped onto the morally dubious and effeminate, associated with feminine concerns of laments, the "broken" and femininity generally. The land of Phrygia contributed associations with the Dionysian cult of debauchery and irrationality. These codings came together with the apparent dangers inhabiting the music itself, and the Phrygian mode was sometimes labeled "war-like". Since the Medieval era the Phrygian mode went "underground" in the West, though still a staple in other parts of the world. It resurfaced occasionally, and very particularly with the Heavy Metal genre which reclassified the medieval "war-like" mode as having "evil" associations, playing it at high volume and low frequency, re-defining it as powerful, active and masculine; apposite connotations for a modern ideology of the anti-hero.

The new masculinity given to the flat second in Metal music may be the first time there has been such a strong connotation of aggression for it since the medieval era's war-like associations, a new and radical signification. Powerful masculine music that is underpinned by the flat second: the trangressive genre has adopted the transgressive note as a mainstay for its aggressive sound, repeating endlessly the assertion of masculinity in continuing, challenging world situations.

\section{Interviews}

Interviews with Luke Raynor, Pete Herbert, Yossi Sa'aron Sassi, Firas Nadaf and Susan McClary conducted by Sarha Moore, in person, between 2009 and 2010 in London, Israel and Los Angeles.

\section{References}


Networking Knowledge: Journal of the MeCCSA Postgraduate Network, Vol. 4, No. 1 (2011)

Austern, L. (1998) “"Forreine conceites and wandring devises”: The exotic, the erotic, and the feminine.' In: Jonathan Bellman (ed.) The Exotic in Western music, Boston: Northeastern University Press, pp. 26-42.

Barker, A. (ed.) (1984) Greek Musical Writings Volume 1: The Musician and his Art. Cambridge: Cambridge University Press.

Biddle, I., Jarman-Ivens, F. (2007) 'Introduction: Oh Boy! Making Masculinity in Popular Music.' In: Jarman-Ivens, F. (ed.) Oh Boy!: masculinities and popular music, New York: Routledge, pp.1-20.

Cooke, D. (1959) The Language of Music. Oxford: Oxford University Press.

Cope, A. (2010) Black Sabbath and the Rise of Heavy Metal Music. Farnham: Ashgate Press.

Deanna, C. (2008) 'Tragic Metal.' Presentation at Music, Metal and Politics MMP 1 conference, Salzburg, Austria.

Fast, S. (2001) In the Houses of the Holy: Led Zeppelin and the Power of Rock Music. New York: Oxford University Press.

Gruzelier, J. (2007) 'Moshpit Menace and Masculine Mayhem.' In: Jarman-Ivens, F. (ed.) Oh Boy!: masculinities and popular music, New York: Routledge, pp.59-76.

Huron, D. (2007) Sweet Anticipation: music and the psychology of expectation. Cambridge: MIT Press.

Kahn-Harris, K. (2007) Extreme Heavy Metal: Music and Culture on the Edge. Oxford: Berg Publishers.

Kepler, J. (1997) The Harmony of the World. Aiton, E.J., Duncan, A.M., Field, J.M. (trans.) Philadelphia: American Philosophical Society.

Killick, A. (2001) 'Music as Ethnic Marker in Film: The “Jewish" Case.' In: Soundtrack Available: Essays on Film and Popular Music. Wojcik, P., Knight, A. (eds.) Durham: Duke University Press, pp. 185-201.

Krenske, L., Mckay, J. (2000) “"Hard and Heavy": gender and power in a Heavy Metal music subculture', Gender, Place and Culture, 7:3, pp. 287-304. 
Networking Knowledge: Journal of the MeCCSA Postgraduate Network, Vol. 4, No. 1 (2011)

Leach, E.E. (2006) 'Gendering the semitone, Sexing the Leading Tone: Fourteenth- Century Music Theory and the Directed Progression', Music Theory Spectrum, 28:1, pp. 1-21.

Maclaren, C. (ed.) (1823) Encyclopedia Britannica, Sixth Edition Volume 16. Edinburgh: A \& C Black.

McClary, S. (2004) Modal Subjectivities: Self fashioning in the Italian madrigal. Berkeley: University of California Press.

Moore, S. (2010) 'Dissonance and Dissidents: The Flattened Supertonic Within and Without of Heavy Metal Music.' In: Heavy Fundametalisms: Music, Metal and Politics, Hill, R., and Spracklen, K. (eds.) Oxford: Inter-Disciplinary Press, pp. 127-141.

Perrin, J. (1997) Megadeth Prime Cuts: Dave Mustaine, Marty Friedman. Milwaukee: Hal Leonard

Pieslak, J. (2008) 'Sound, text and identity in Korn's “Hey Daddy”, Popular Music, 27: 35-52.

Pieslak, J. (2009) Sound Targets: American Soldiers and Music in the Iraq War. Bloomington: Indiana University Press.

Peisner, D. (2006) 'Music as Torture: War is Loud' Spin. Available from: http://www.spin.com/articles/music-torture-war-loud?page $=0 \% 2 \mathrm{C} 4$ (accessed $13^{\text {th }}$ June 2111).

Pillsbury, G. (2006) Damage Incorporated: Metallica and the Production of Identity. New York: Routledge.

Powers, H. S., et al. (2001) 'Mode.' In: New Grove Dictionary of Music and Musicians second edition Volume 16.

Puri, S. (2010) 'Machine Guns and Machine Gun Drums: Heavy Metal's Portrayal of War.' In: Heavy Fundametalisms: Music, Metal and Politics, Hill, R., and Spracklen, K. (eds.) Oxford: Inter-Disciplinary Press, pp. 55-69.

Ra'ad, B.L. (2005) 'Subliminal Filmic Reflections', Quarterly Review of Film and Video, 22: 371-377.

Rouget, G. (1985) Music and trance: a theory of the relations between music and possession . Chicago: University of Chicago Press.

Said, E. (1978) Orientalism: Western Conceptions of the Orient. New York: Penguin. 
Networking Knowledge: Journal of the MeCCSA Postgraduate Network, Vol. 4, No. 1 (2011)

Sumera, M. (Forthcoming) "Sounding War Online." In Virtual War and Magical Death: Technologies and Imaginaries for Terror and Killing, Sverker Finnstrom, S., and Neil L. Whitehead, N. (eds.) Duke University Press.

Tagg, P., Clarida, B., (2003) Ten Little Title Tunes. New York: The Mass Media Music Scholars' Press Inc.

Tagg, P. (1993) “'Universal” music and the case of death', Critical Quarterly, 35: 54-85.

Taylor, T. (2007) Beyond Exoticism: Western Music and the World. Durham: Duke University Press.

Walser, R. (1992) 'Eruptions: Heavy Metal Appropriations of Classical Virtuosity', Popular Music, Vol. 11,3: 263-308.

(1993) Running With the Devil: power, gender, and madness in Heavy Metal music. USA: Wesleyan University Press.

Wyss, E. (1996) The Myth of Apollo and Marsyas in the Art of the Italian Renaissance: An Enquiry into the Meaning of Images. Delaware: University of Delaware Press.

Yıldırım, D. (2009) 'Harder, Faster, Stronger: Representations of Masculinities in Heavy Metal Music', Presentation at Music, Metal and Politics MMP 2 conference, Salzburg, Austria.

Žižek, S. (1994) The Metastases of Enjoyment: Six Essays on Women and Causality (Wo Es War). Verso Books.

\section{Discography}

Al Qaynah (2007) 'Ground Zero Pilgrims'. Available from: http://www.facebook.com/pages/AlQaynah/108119950251 (accessed 14th June 2011).

Arch Enemy (2004) 'Dead Eyes See No Future', Anthems of Rebellion, Century Media Records. B001OHSBDQ

Black Sabbath (1970) 'Hand of Doom', Paranoid, Warner Bros. B001F39V1A

Chaos (2011) 'Silence before Chaos'. Available from: www.youtube.com/watch? $v=$ giIaVWZy4OY (accessed 30 $0^{\text {th }}$ April 2011). 
Networking Knowledge: Journal of the MeCCSA Postgraduate Network, Vol. 4, No. 1 (2011)

Chopin, F. 'Valse Brillante' in A Minor, Op. 34 No. 2 - Lento, Chopin: Waltzes played by Alice Sara Ott. Decca B002WHTGC2 (2010). Available from: www.chopinmusic.net/works/waltzes/ (accessed $28^{\text {th }}$ February 2011).

Deep Purple (1974) “Stormbringer”, Stormbringer, Warner Brothers. B004ER2SNM

Drowning Pool (2001) 'Sinner', Sinner, Wind-up. B00006O9X6

'Bodies', Sinner, Wind-up. B00006O9X6

Iron Maiden (1984) 'Powerslave', Powerslave. B000063DFN

Led Zeppelin (1969) 'Dazed and Confused', Led Zeppelin, Atlantic B000TB60UO

Metallica (1992) 'Wherever I may Roam', The Black Album, Elektra Records. B000002H97

Ministry (2006) 'Khyber Pass', Rio Grande Blood, $13^{\text {th }}$ Planet. B000D2Q6ZS

Slayer (1986) 'Angel of Death', Reign in Blood, Warner Brothers B000002KZU

System of a Down (1998) 'Sugar', System of a Down, Sony B000007T1M

Trivium (2005) 'Pull harder on the strings of your Martyr', Ascendancy, Roadrunner Records B0007QN8U6

Van Halen (1978) 'Eruption', Van Halen, Warner Brothers B004EQW3OM

Verdelot, P. 'O Dolce Notte', Madrigals for a Tudor King (Skinner). Obsidian. OBSID-CD703

\section{Videography}

The Hurt Locker. 2009. Dir. Kathryn Bigelow. Music by Marco Beltrami, Buck Sanders. Santa Monica: Summit Entertainment.

Jaws. 1975. Dir. Stephen Spielberg. Music by John Williams. Hollywood: Universal Pictures.

'Military Clip let the Bodies Hit the Floor'. Available from: www.youtube.com/watch? $\mathrm{v}=\mathrm{dT}$ zo9MzRvo\&feature=related (accessed 4th March 2011).

'Recon Marine Recruiting Video'. Available from: www.youtube.com/watch?v=g-79oCEKJE0 (accessed 4th March 2011).

'Your First 80 Days (1966) - Marine Corps Recruit Training'. Available from: www.youtube.com/watch? v=nSa96KakIZw (accessed 4th March 2011). 
Networking Knowledge: Journal of the MeCCSA Postgraduate Network, Vol. 4, No. 1 (2011)

'Yngwie Malmsteen: heavy e phrygian'. Available from: www.video.google.com/videoplay? docid $=5789643979090107390 \#\left(\right.$ accessed $4^{\text {th }}$ June 2011) 